\title{
Molecular mechanisms linking periimplantitis and type 2 diabetes mellitus revealed by transcriptomic analysis
}

\author{
Tianliang Yu ${ }^{1}$, Aneesha Acharya ${ }^{2,3}$, Nikos Mattheos ${ }^{2}$, Simin Li ${ }^{4}$, Dirk Ziebolz ${ }^{4}$, Gerhard Schmalz ${ }^{4}$, Rainer Haak ${ }^{4}$, \\ Jana Schmidt $^{4}$, Xiangqiong Liu ${ }^{5}$, Yupei Deng ${ }^{5}$, Yu Sun ${ }^{\text {Corresp. } 1}$ \\ ${ }^{1}$ Department of Prosthodontics, School of Dentistry, Harbin Medical University, Harbin, Heilongjiang, China \\ 2 Faculty of Dentistry, University of Hong Kong, Hong Kong, China \\ 3 Dr D Y Patil Dental College and Hospital, Pimpri, Pune, India \\ 4 Department of Cariology, Endodontology and Periodontology, University Leipzig, Leipzig, Saxon, Germany \\ 5 Shanghai Genomap Technologies, Shanghai, China \\ Corresponding Author: Yu Sun \\ Email address: sunyu20060212@126.com
}

Aims: To explore molecular mechanisms that link periimplantitis and type 2 diabetes mellitus (T2DM) by bioinformatic analysis of publicly available experimental transcriptomic data.

Materials and methods: Gene expression data from periimplantitis were downloaded from the GEO database, integrated and differentially expressed genes (DEGs) in periimplantitis were identified. Next, experimentally validated and computationally predicted genes related to T2DM were downloaded from the DisGeNET database. Protein-protein interaction network (PPI) pairs of DEGs related to periimplantitis and T2DM related genes were constructed, 'hub' genes and overlapping DEG were determined.

Functional enrichment analysis was used to identify significant shared biological processes and signaling pathways. The PPI networks were subjected to cluster and specific class analysis for identifying 'leader' genes. Module network analysis of the merged PPI network identified common or cross-talk genes connecting the two networks.

Results: A total of 92 DEGs overlapped between periimplantitis and T2DM datasets. Three hub genes (IL-6, NFKB1, and PIK3CG) had the highest degree in PPI networks of both periimplantitis and T2DM. Three leader genes (PSMD10, SOS1, WASF3), eight cross-talk genes (PSMD10, PSMD6, EIF2S1, GSTP1, DNAJC3, SEC61A1, MAPT, and NME1) and one signaling pathway (IL-17 signaling) emerged as periimplantitis and T2DM linkage mechanisms.

Conclusions: Exploration of available transcriptomic datasets revealed IL-6, NFKB1, and PIK3CG expression along with the IL-17 signaling pathway as top candidate molecular linkage mechanisms between periimplantitis and T2DM. 
1 Molecular mechanisms linking periimplantitis and type 2 diabetes mellitus revealed by

2 transcriptomic analysis.

3 Tianliang $\mathrm{Yu}^{1}$, Aneesha Acharya ${ }^{2,3}$, Nikos Mattheos ${ }^{2}$, Simin $\mathrm{Li}^{4}$, Dirk Ziebolz ${ }^{4}$, Gerhard

$4 \mathrm{Schmalz}^{4}$, Rainer $\mathrm{Haak}^{4}$, Jana Schmidt ${ }^{4}$, Yu Sun ${ }^{1 *}$.

5 1. Department of Prosthodontics, School of Dentistry, Harbin Medical University, Harbin, $6 \quad$ Heilongjiang, China.

7 2. Faculty of Dentistry, University of Hong Kong, Hong Kong, China.

8 3. Dr D Y Patil Dental College and Hospital, Dr D Y Patil Vidyapeeth, Pimpri, Pune, India.

9 4. Department of Cariology, Endodontology and Periodontology, University Leipzig, Leipzig,

10 Saxon, Germany.

\section{Corresponding Author:}

$13 *$ Dr. Yu Sun 


\section{Abstract}

24 Aims: To explore molecular mechanisms that link periimplantitis and type 2 diabetes mellitus

25 (T2DM) by bioinformatic analysis of publicly available experimental transcriptomic data.

Materials and methods: Gene expression data from periimplantitis affected tissues were downloaded from the GEO database, integrated, differentially expressed genes (DEGs) in periimplantitis were identified and functional enrichment analysis. Next, experimentally validated and computationally predicted genes related to T2DM were downloaded from the DisGeNET database. Functional enrichment analysis identified significant biological processes and signaling pathways. Protein-protein interaction networks (PPI) for DEGs related to periimplantitis, and for T2DM-related genes were each constructed, 'hub' genes, and overlapping genes were determined. Cluster and specific class analyses of PPI networks identified 'leader' genes, and, module network analysis of a merged PPI network identified 'cross-talk' genes connecting the two networks.

Results: A total of 92 DEGs overlapped between periimplantitis and T2DM datasets. Three hub genes (IL-6, NFKB1, and PIK3CG) had the highest degree in PPI networks of both periimplantitis and T2DM. Three leader genes (PSMD10, SOS1, WASF3), eight cross-talk genes

39 (PSMD10, PSMD6, EIF2S1, GSTP1, DNAJC3, SEC61A1, MAPT, and NME1) and one signaling pathway (IL-17 signaling) emerged as periimplantitis and T2DM linkage mechanisms.

41 Conclusions: Exploration of available transcriptomic datasets revealed IL-6, NFKB1, and PIK3CG expression along with the IL-17 signaling pathway as top candidate molecular linkage 
mechanisms between periimplantitis and T2DM.

\section{Introduction}

With the increasing use of dental implants in oral rehabilitation, peri-implant inflammatory diseases have risen in incidence and comprise a significant clinical challenge. Peri-implant disease constitutes of peri-implant mucositis, characterized by reversible inflammation restricted to soft tissues around an implant, and, periimplantitis, characterized by peri-implant alveolar bone loss due to progression of the inflammatory lesion (Renvert et al. 2018). Being multifactorial, periimplantitis is associated with a number of risk factors (Dreyer et al. 2018). Diabetes mellitus, a common metabolic disorder, is characterized by hyperglycemia resulting from insulin resistance, inadequate insulin secretion, or excessive glucagon secretion (Blair 2016). Type 2 diabetes (T2DM), the main form of diabetes affecting $90-95 \%$ of diabetics, is a risk factor for periimplantitis (Dreyer et al. 2018, Monje et al. 2017), with a 50\% higher risk reported in a metaanalysis (Monje et al. 2017). Others have noted disease severity of periimplantitis increases with worse glycemic control in T2DM (Al Amri et al. 2016, Gómez-Moreno et al. 2015).

Pathogenic mechanisms underlying T2DM mediated aggravation of peri-implant diseases are not as well-investigated and remain poorly understood. A common understanding is that impairment of vascularization and angiogenesis inherent to a T2DM microenvironment impairs bone healing by delaying wound healing, reducing bone formation, and impairing osteogenesis (Marin et al. 2018). Notably, diabetes mellitus alters host-immune responses, skewing these towards pro- 
64 inflammatory dominance (Nielsen et al. 2017). As a result, in diabetics, the cytokine production

65 in response to peri-implant biofilm can be be altered, when compared to that in healthy subjects.

66 Among individuals with peri-implantits, those having diabetes show an overproduction of

67 multiple peri-implant fluid pro-inflammatory cytokines; IL-1, IL-6, IL-8, TNF-alpha, chemokine

68 receptors CCR5 and CXR3 (Venza et al. 2010, Al-Askar et al. 2018), where the severity of

69 dysregulation appears to be worsen with poor diabetic control. Such unfavorable immune

70 modulation is likely to cause the higher susceptibility to peri-implantitis noted in diabetics

71 (Monje et al. 2017). Other mechanisms whereby peri-implantitis is aggravated in a poorly

72 controlled diabetic mileu include potential alterations in biofilm composition (Gulia et al. 2018)

73 and accumulation of advanced glycation end products (Al-Sowygh et al. 2018, Alrabiah et al.

74 2018). Nevertheless, to the authors' knowledge, not much is known about the scale of molecular

75 relationships between both diseases. The identification of linkage molecular mechanisms could

76 translate to potential therapeutic targets for individualized treatment of periimplantitis in T2DM

77 affected subjects.

79 Integrated analysis of bioinformatic data has several advantages in scoping poorly understood

80 disease associations. Relevant genomic data from multiple microarray and next-generation

81 sequencing studies of single diseases can be used to detrmine molecular linkages through

82 bioinformatic analyses. Several microarray or sequencing studies have examined global gene-

83 expression patterns relevant to periimplantitis (Becker et al. 2014, Schminke et al. 2015) and to

84 T2DM (Berisha et al. 2011, Pihlajamäki et al. 2009, Taneera et al. 2013), each. An overview of 
these studies suggests some similarities in the molecular mechanisms implicated in both diseases. These include inflammatory cytokines (Interleukin-1 $\beta$, Interleukin-6), vascular endothelial growth factor (VEGF), and reactive oxygen species (ROS)-related genes. By integrative bioinformatics, genomic data from T2DM and periimplantitis documented in previous studies can facilitate the identification of potential molecular links. Therefore, a bioinformatic study of existing experimental transcriptome datasets was designed to investigate putative molecular links between periimplantitis and T2DM by identifying cross-talk genes, biological processes, and signaling pathways involved in both diseases.

\section{Materials and methods:}

Procurement of data: Two transcriptome datasets pertaining to periimplantitis (GSE33774 and GSE57631) were downloaded from Gene Expression Omnibus (GEO) database (http://www.ncbi.nlm.nih.gov/projects/geo/). The diagnostic criteria of periimplantitis in each study was aligned with the current consensus case-definition of periimplantitis: radiographic evidence of bone loss $\geq 3 \mathrm{~mm}$ and/or probing depths $\geq 6 \mathrm{~mm}$ in conjunction with profuse bleeding (Renvert et al. 2018). For the dataset GSE33774, a probing depth $\geqq 5 \mathrm{~mm}$ in combination with radiographic bone loss around implants $>3 \mathrm{~mm}$ were indicative of periimplantitis (Becker et al. 2014). For the dataset GSE57631, the diagnostic criteria of periimplantitis were not specified in the relevant text (Schminke et al. 2015) and by contacting the authors (Schminke et al. 2015), these were determined as consistent with the current consensus criteria (Renvert et al. 2018). 
106

Experimentally validated and computationally predicted genes associated with T2DM were downloaded from the DisGeNET database (http://www.disgenet.org/home/). The DisGeNET database is a comprehensive platform that integrates information concerning human diseaseassociated genes and their variants (Piñero et al. 2016). This database integrates data from expert curated repositories, text mining data extracted from scientific literature, experimentally validated data, and referred data (Piñero et al. 2016). By using this database, a total of 1,274 T2DM-associated genes were determined.

Differential gene expression and functional enrichment analysis: The two periiimplantitisrelated transcriptome datasets were subjected to differential expression analysis using the 'limma' package in $\mathrm{R}$ (Ritchie et al. 2015). Periimplantitis-related genes with $\mathrm{p}$ value $<0.05$ and $|\log \mathrm{FC}|>=1$ were screened and defined as differentially expressed genes (DEGs). Next, enrichment analysis was performed with the R package 'clusterProfiler' to describe the Gene Ontology (GO) and Kyoto Encyclopedia of Genes and Genomes (KEGG) functional profiles of the DEGs related to periimplantitis.

Protein-protein interaction network analysis: Protein-protein interaction (PPI) pairs of DEGs related to periimplantitis and genes related to T2DM were each determined using the free webavailable database Search Tool for the Retrieval of Interacting Genes (STRING) (Release 9.1, http://string-db.org/), as it has medium to high confidence scores. Based on these PPI pairs, PPI networks were constructed for each periimplantitis and T2DM respectively, and the topological 
127

128

129

130

131

132

133

134

135

136

137

characteristics of the two PPI networks were analyzed.

Clustering analysis: A 'combined association score' (CAS) of each PPI pair, representing the interacting pair's degree of confidence, was determined. The CAS for each gene over that of its neighbors was summed and defined as 'comscore', which represented the number of weighted links for that gene. K-means clustering analysis was applied to these 'comscores' and gene nodes were classified into 5 classes according to their weighted number of links. Specific class analysis was performed by determination of K-means based classes specific to and significantly associated with periimplantitis and T2DM each, by using analysis of variance and multipletesting with Tukey-Kramer test $($ at $\mathrm{p}<0.01)$. Genes in these classes were further analyzed. Genes belonging to the highest rank were defined as 'leader genes', as these genes had the highest weighted number of links as compared to others in that network. The 'leader gene' approach enables the identification of a small number of potentially most relevant candidate genes from the experimental dataset.

Cross-talk gene analysis: PPI networks for periimplantitis and T2DM were merged to construct a global network. T2DM related genes among the DEGs associated to periimplantitis were identified as cross-talk genes. Module networks of these cross-talk genes were constructed using a graph theoretic clustering algorithm "Molecular Complex Detection" (MCODE). Modules represent genes that are densely connected in a PPI network are likely to represent highly related protein complexes or modules. 


\section{Results}

150

151

152

153

154

155

156

157

158

159

160

161

162

163

164

165

166

167

168

Identification of DEGs: The DEGs identified in periimplantitis are listed in Table S1. 224

DEGs were identified in GSE33774 and 813 DEGs were identified in GSE57631. Combining these, a total of 1028 genes emerged as associated with periimplantitis. For T2DM, a total of 1274 genes were obtained. 92 of the DEGs were shared by periimplantitis and T2DM (Fig S1).

Functional enrichment analysis: DEGs in periimplantitis were mainly involved in the biological processes (BPs) of neutrophil activation, neutrophil mediated immunity, antigen processing and presentation of peptide antigen via MHC class I, and positive regulation of protein catabolic process (Fig S2). Genes associated with T2DM were mainly enriched in BPs of response to nutrient levels and response to oxidative stress (Fig S3). No BP emerged as overlapped between periimplantitis and T2DM. In terms of KEGG signaling pathways, DEGs associated with periimplantitis were seen as mainly related to protein processing in endoplasmic reticulum, IL-17 signaling pathway, and Leukocyte transendothelial migration (Fig S4). Genes related to T2DM were significantly enriched in pathways related to insulin resistance and FoxO signaling (Fig S5). Combining these, a single signaling pathway; IL-17 signaling, was seen as shared by periimplantitis and T2DM.

PPI network analysis: The PPI network in periimplantitis showed 786 nodes and 5278 
169

170

171

172

173

174

175

176

177

178

179

180

181

182

183

184

185

186

187

interaction pairs (Fig 1a) whereas, that in T2DM showed 1171 nodes and 26862 interaction pairs

(Fig 1b). The topological characteristics of the two PPI networks are summarized in Table S2, where gene nodes are ranked in descending order of their degree, and the top 20 nodes or 'hub genes' were determined. Among these top 20 hub genes, three genes (IL6, NFKB1, and PIK3CG) were common to periimplantitis and T2DM, thus can be regarded as the potential cross-talk genes. Considering these hub genes appeared to be central to the regulation of and may prominently impact the biological network, PPI subnetworks of these three genes were extracted (Fig 2). In the leader gene approach, cluster analyses for periimplantitis showed the class 2 as the most significantly associated class (Fig S6a) and for T2DM, the class 3 as the most significant (Fig S6b). Extracting the genes in these classes, three leader genes; PSMD10, SOS1, and WASF3 were found to be overlapping (Table S3).

Module network analysis: Module network analysis of the cross-talk genes showed 3 subnetworks. Module subnetwork 1, where red nodes represent the common genes, green nodes represent $\mathrm{T} 2 \mathrm{DM}$ genes and blue nodes are DEGs associated with periimplantitis, showed PSMD10 and PSMD6 as cross-talk genes, which directly interacted with one gene closely related to diabetes (LTA), as well as with DEGs in periimplantitis (PSM family genes (PSMC2, PSMA4, PSME4, et al), SKP2, EIF3F. USP14, UBLCP1, et al) (Fig 3). In module subnetwork 2 (Fig 4), five cross-talk genes; EIF2S1, GSTP1, DNAJC3, SEC61A1, and MAPT were noted, which directly interacted with a few T2DM genes and DEGs of periimplantitis. Module subnetwork 3 (Fig 5), showed only one common gene (NME1), interacting with small number of genes 
190

191

192

193

194

195

196

197

198

199

200

201

202

203

204

205

206

207

208

209

210

involved in both networks.

Known functions of the key hub genes and cross talk genes in T2DM and periimplantitis each are described in Table 1.

\section{Discussion}

The current study included both peri-implant bone and peri-implant soft tissue transcriptomes and the findings can be considered as an integrated or non-specific view of periimplantitisT2DM molecular linkages. Three common or cross-talk genes; IL-6, NFKB1, and PIK3CG, were noted among the top 20 hub genes in the PPI networks of T2DM and periimplantitis. Raised interleukin (IL)-6 has been demonstrated as an independent predictor of T2DM (Akbari and Hassan-Zadeh 2018). IL-6 promotes inflammation and can induce insulin resistance (Rehman et al. 2017). IL-6 expression is also increased in periimplantitis, reflecting its role in destruction of peri-implant tissue and bone resorption by exerting proinflammatory effects (Martí et al. 2011).

Raised IL-6 in the peri-implant crevicular fluid has been proposed as a marker of periimplantitis (Yaghobee et al. 2014). The NFKB1 gene is a transcription factor which encodes the nuclearfactor kappa beta (NF-kB) p105/p50 isoforms (Héron et al. 1995). NF-kB inflammatory signaling is implicated in the development of T2DM (Baker et al. 2011) and experimetal evidence shows interfering with NF-kB signalling can decrease hyperglycemia and insulin resistance. In periimplantitis, NFKB1 has been previously identified as a key candidate gene 
211 (Zhang et al. 2017) and is shown to regulate inflammation-induced osteoclastogenesis by

212 regulating receptor activator of $\mathrm{NF}-\kappa \mathrm{B}$ ligand (RANKL) - mediated osteoclast formation and

213 activation in periimplantitis (Boyce et al. 2015). The phosphoinositide-3 kinase (PI3K, also

214 called PIK3CG) is an important regulator of cell response to extra-cellular stimuli. PI3KCG gene

215 encodes a class I catalytic subunit of PI3K protein, which can bind a p85 regulatory subunit to

216 form PI3K (Amzel et al. 2008). In T2DM, PI3K activity reduction impairs insulin signal

217 transduction an impairs translocation of glucose transporter protein GLUT4 leading to insulin

218 resistance (Niswender et al. 2003). PI3K signaling is also shown to increase the osteogenic

219 differentiation of periodontal ligament stem cells (Lee et al. 2014a), thus, could be implicated in

220 periimplantitis via regulation of osteogenesis. Thus, experimental evidence supports the notion

221 that the in-silico determined shared genes could be significant mechanistic links between T2DM

222 and periimplantitis.

223

224 Three common leader genes; PSMD10, SOS1, and WASF3, were identified from the gene

225 clusters linked to periimplantitis and T2DM each. Proteasomes are involved in intracellular

226 protein degradation and implicated in several diseases. The PSMD10 or Gankyrin gene

227 (proteasome 26S subunit, non-ATPase 10) encodes subunits of the 26S proteasome, a component

228 of the ubiquitin-proteasome (UPS) system (Hochstrasser 1996). It has been found enriched in

229 inflammation (Lecker et al. 2006) and may be induced by pro-inflammatory Interleukin-1 beta

230 stimulation ( $\mathrm{Su}$ et al. 2015). It is upregulated in T2DM (Costes et al. 2011), and was also

231 implicated previously in periimplantitis (Zhang et al. 2017) but no experimental evidence exists. 
232 SOS1 (SOS Ras/Rac guanine nucleotide exchange factor 1) regulates Rat sarcoma proteins and

233 facilitates exchange of GTP for GDP. In T2DM, Ras-GTPase has been implicated in inducing

234 aberrant vascular reactivity and dysfunction (Yousif et al. 2004). In periimplantitis, while SOS1

235 was previously identified as a hub gene (Zhang et al. 2017) but experimental evidence is

236 similarly lacking. Ras activation is an early signal for osteogenesis in human bone marrow

237 stromal cells (BMSCs) (Wang et al. 2001). The Ras superfamily is also suggested to regulate

238 inflammation by acting as regulators of NF- $\mathrm{KB}$ and Ral pathways (Oeckinghaus et al. 2014).

239 WASF3 (WAS protein family member 3) controls actin binding, thus regulating cell shape and

240 motility, and has been frequently implicated in cancer cell motility and metastasis (Teng et al.

241 2016). As glucose transporter recruitment is actin dependent, a plausible role of WASF3

242 signaling in T2DM pathology is suggestible (Tunduguru et al. 2017). In addition, actin binding

243 was found as a significantly dysregulated process by a whole-exome sequencing study of

244 periimplantitis (Lee et al. 2014b), but no experimental study has yet characterized WASF3's

245 expression in peri-implantitis.

246

247 Module network analysis identified 8 cross-talk genes; PSMD10, PSMD6, EIF2S1, DNAJC3,

248 SEC61A1, GSTP1, MAPT, and NME1. Like PSMD10, PSMD6 is regulatory for the 26S

249 proteasome, which is central to protein regulation by ubiquitination-degradation. UPS

250 dysregulation might be a molecular mechanisms underlying insulin resistance

251 (Balasubramanyam et al. 2005) and has also been implicated in microvascular complications of

252 T2DM (Aghdam et al. 2013). In periimplantitis, proteasomal ubiquitin-dependent protein 
253

254

255

256

257

258

259

260

261

262

263

264

265

266

267

268

269

270

271

272

273

catabolic process (GO term: 0043161) was found to be significantly enriched (Zhang et al. 2017).

Based on these perspectives, it may be hypothesisized that UPS dysregulation in a T2DM state contributes to aggravated periimplantitis via a positive feedback loop, wherein pro-inflammatory cytokine responses to periimplant biofilm may further its dysregulation. EIF2S1 is a component of the PI3K pathway, encoding for the eukaryotic initiation factor $2 \alpha$ (eIF $2 \alpha$ ) involved in regulating protein synthesis (Jiang and Wek 2005) and endoplasmic reticulum (ER) stress responses. Activation of eIF $2 \alpha$-mediated signaling by bacterial pathogens downregulates infection-induced cytokine expression (Shrestha et al. 2012) and may propogate the inflammatory processes. It is also implicated in T2DM, as dysregulation of eIF2 $\alpha$ leads to pancreatic $\beta$ cells dysfunction (Cnop et al. 2017). The expression pattern or effects of eIF $2 \alpha$ in periimplantitis are not specifically investigated. Among the genes noted in module subnetwork 2 , DNAJC3 (DnaJ Heat Shock Protein Family (Hsp40) Member C3 or P58IPK) inhibits eIF-2 $\alpha$ signaling, thereby attenuating the later phases of the endoplasmic reticulum (ER) stress response (Ladiges et al. 2005). DNAJC3 mutation is implicated in the development of T2DM via dysfunction of insulin-secreting beta cells (Ladiges et al. 2005). In periimplantitis it can activate the unfolded protein response (UPR) pathway associated with inflammation and alveolar bone resorption (Yamada et al. 2015). The possible mechanisms of SEC61A1 (Sec61 Translocon Alpha 1 Subunit) in T2DM and periimplantitis appear to be similar to those of the DNAJC3 gene. SEC61A1 is also related to ER stress response by control of polypeptide transport into ER (Lang et al. 2012). GSTP1 (Glutathione S-Transferase Pi 1) is suggested to protect cells against oxidative stress (Savic-Radojevic et al. 2007), which is involved in both periimplantitis 
274 (Sánchez-Siles et al. 2016) and T2DM (Wright Jr et al. 2006) pathology. GSTP1 polymorphism

275 is associated with susceptibility to type II diabetes mellitus (Saadat 2017) and the risk for

276 developing chronic periodontitis (Camargo Ortega et al. 2014) and could similarly imply risk for

277 its analogue periiimplantitis (Dhir et al. 2013). The microtubule associated protein Tau (MAPT),

278 a member of the MAP family regulated microtubule function within the cell cytoskeleton

279 (Sündermann et al. 2016). Disturbance in MAPT phosphorylation is shown to decrease insulin

280 production from pancreatic beta cells, supporting its role in T2DM pathology (Maj et al. 2016).

281 MAPT gene polymorphism is also implicated in bone mineral density regulation (Dengler-Crish

282 et al. 2017). NME1 (NME/NM23 Nucleoside Diphosphate Kinase 1) is a known negative

283 regulator of nuclear factor- $\kappa \mathrm{B}$ signaling (You et al. 2014). Considering nuclear factor- $\kappa \mathrm{B}$

284 signaling has been shown to be dysregulated and involved in pathogenesis of both T2DM

285 (Andreasen et al. 2011) and periimplantitis (Rakic et al. 2013), NME1 may be a relevant

286 upstream molecular link between T2DM and periimplantitis.

288 IL-17 signaling emerged as the sole pathway significantly shared between T2DM and 289 periimplantitis. IL-17 plays critical regulatory roles in host defense and inflammatory diseases 290 showing both protective and destructive effects (Zou et al. 2013). Although IL-17 protects 291 against pathogen invasion at epithelial or mucosal barriers, its dysregulation can stimulate 292 overexpression of pro-inflammatory cytokines (IL-1 $\beta$, IL-6, TNF- $\alpha$ ) leading to continued tissue 293 damage (Jin and Dong 2013). IL-17 overexpression is noted in peri-implant crevicular fluid of 294 periimplantitis (Severino et al. 2016) and serum of T2DM (Nadeem et al. 2013). IL-17 
295

296

297

298

299

300

301

302

303

304

305

306

307

308

309

310

311

312

313

314

315

negatively impacts osteogenesis in periimplantitis affected tissue (Kim et al. 2014). In T2MD,

IL-17 can contribute to exacerbation of insulin resistance by inducing apoptosis of pancreatic $\beta$ cells (Yousefidaredor et al. 2014). Considering that IL-17 antagonist molecules have recently emerged as therapeutics, this finding may suggest a basis to explore their therapeutic potential in T2DM affected periimplantitis patients (Abdel-Moneim et al. 2018).

Taken together, perspectives from prior literature support biological basis for many of the significant genes and pathways that emerged as putative mechanistic links between periimplantitis and T2DM. The major limitation of the study is lack of experimental validation of the genes highlighted in the in-silico analyses which was beyond the scope of the current investigation. Thus, these findings have significant implications for future research. Most of the linkage genes revealed by the study lack experimental evidence in context of periimplantitisT2DM disease association. In theory, these molecular entities could be valuable as potential targets for individualized gene therapy, risk stratification, and therapy of periimplantitis in type 2 diabetes. Further validation of key molecular mechanisms could promote the development of targeted drugs for blocking or aiding their expression and modulating related pathways. Most importantly, the present findings may be considered as hypotheses for future validation experiments and direction for research. As such, bioinformatic data mining of experimental transcriptomes is exploratory and at best considered as a source of well-supported hypotheses. Validation experiments could include comparison of the highlighted genes' expression levels in the peripheral blood and peri-implant crevicular fluid of periimplantitis affected individuals with 
316 and without T2DM and explore their roles in-vitro/animal disease models.

317

318 Conclusion

319 Bioinformatics analysis combining experimental transcriptomic data from T2DM and

320 periimplantitis revealed potentially shared molecular linkages. Three hub genes (IL-6, NFKB1,

321 and PIK3CG) identified in PPI networks, three cross-talk genes (PSMD10, SOS1, and WASF3)

322 identified by specific class analysis and eight cross-talk genes (PSMD10, PSMD6, EIF2S1,

323 GSTP1, DNAJC3, SEC61A1, MAPT, and NME1) obtained by module network analysis, and IL-

32417 signaling emerged as top candidate shared molecular linkages. Future studies should explore

325 their roles in context of T2DM-periimplantitis disease association.

326

327

\section{Acknowledgements}

328 We are grateful to Ms. Xiangqiong Liu (Email: dr.xqliu.bioinformatics@gmail.com) and Mr.

329 Yupei Deng (Email: yupei.deng.bioinformatics@gmail.com), who are bioinformatics engineers

330 at Shanghai Genomap Technologies, Shanghai, China. We have to express our appreciation to

331 them for providing us some technological assistance during the analyzing course of this research.

References:

334 Abdel-Moneim A, Bakery HH, Allam G. 2018. The potential pathogenic role of IL-17/Th17

335 cells in both type 1 and type 2 diabetes mellitus. Biomed Pharmacother 101:287-292. DOI:

$336 \quad$ 10.1016/j.biopha.2018.02.103. 
337 Aghdam SY, Sheibani N. 2013. The ubiquitin-proteasome system and microvascular 338 complications of diabetes. J Ophthalmic Vis Res 8:244-256.

339

340

341

342

343

344

345

346

347

348

349

350

351

352

353

354

355

356

357

Akbari M, Hassan-Zadeh V. 2018. IL-6 signalling pathways and the development of type 2 diabetes. Inflammopharmacology 26:685-698. DOI: 10.1007/s10787-018-0458-0.

Al-Askar M, Ajlan S, Alomar N, Al-Daghri NM. 2018. Clinical and Radiographic Peri-Implant Parameters and Whole Salivary Interleukin-1 $\beta$ and Interleukin-6 Levels among Type-2 Diabetic and Nondiabetic Patients with and without Peri-Implantitis. Med Princ Pract 27:133-138. DOI: 10.1159/000488032.

Al-Sowygh ZH, Ghani SMA, Sergis K, Vohra F, Akram Z. 2018. Peri-implant conditions and levels of advanced glycation end products among patients with different glycemic control. Clin Implant Dent Relat Res 20:345-351. DOI: 10.1111/cid.12584.

Al Amri MD, Kellesarian SV, Al-Kheraif AA, Malmstrom H, Javed F, Romanos GE. 2016. Effect of oral hygiene maintenance on HbAlc levels and peri-implant parameters around immediately-loaded dental implants placed in type-2 diabetic patients: 2 years follow-up. Clin Oral Implants Res 27:1439-1443. DOI: 10.1111/clr.12758.

Alrabiah M, Al-Aali KA, Al-Sowygh ZH, Binmahfooz AM, Mokeem SA, Abduljabbar T. 2018. Association of advanced glycation end products with peri-implant inflammation in prediabetes and type 2 diabetes mellitus patients. Clin Implant Dent Relat Res 20: 535-540. DOI: $10.1111 /$ cid.12607.

Amzel LM, Huang CH, Mandelker D, Lengauer C, Gabelli SB, Vogelstein B. 2008. Structural comparisons of class I phosphoinositide 3-kinases. Nat Rev Cancer 8:665-669. DOI: 
Andreasen AS, Kelly M, Berg RM, Møller K, Pedersen BK. 2011. Type 2 diabetes is associated with altered NF-kappaB DNA binding activity, JNK phosphorylation, and AMPK phosphorylation in skeletal muscle after LPS. PLoS One 6:e23999. DOI: 10.1371/journal.pone.0023999.

Baker RG1, Hayden MS, Ghosh S. 2011. NF-кB, inflammation, and metabolic disease. Cell Metab 13:11-22. DOI: 10.1016/j.cmet.2010.12.008.

Balasubramanyam M, Sampathkumar R, Mohan V. 2005. Is insulin signaling molecules misguided in diabetes for ubiquitin-proteasome mediated degradation? Mol Cell Biochem 275:117-125.

Becker ST, Beck-Broichsitter BE, Graetz C, Dörfer CE, Wiltfang J, Häsler R. 2014. profiling. Clin Implant Dent Relat Res 16:401-411. DOI: 10.1111/cid.12001.

Berisha SZ, Serre D, Schauer P, Kashyap SR, Smith JD. 2011. Changes in whole blood gene expression in obese subjects with type 2 diabetes following bariatric surgery: a pilot study. PLoS One 6:e16729. DOI: 10.1371/journal.pone.0016729.

Blair, M. 2016. Diabetes Mellitus Review. Urol Nurs 36:27-36.

Boyce BF, Xiu Y, Li J, Xing L, Yao Z. 2015. NF-кB-mediated regulation of osteoclastogenesis. Endocrinol Metab (Seoul) 30:35-44. DOI: 10.3803/EnM.2015.30.1.35.

Camargo Ortega VR, Bravo López LD, Visoso Salgado A, Mejia Sanchez F, Castillo Cadena J. 
Cnop M, Toivonen S, Igoillo-Esteve M, Salpea P. 2017. Endoplasmic reticulum stress and eIF2 $\alpha$ phosphorylation: the Achilles heel of pancreatic $\beta$ cells. Mol Metab 6:1024-1039. DOI: 10.1016/j.molmet.2017.06.001.

Costes S, Huang CJ, Gurlo T, Daval M, Matveyenko AV, Rizza RA, Butler AE, Butler PC. 2011.

Dhir S, Mahesh L, Kurtzman GM, Vandana KL. 2013. Peri-implant and periodontal tissues: a review of differences and similarities. Compend Contin Educ Dent 34:e69-75.

Dreyer H, Grischke J, Tiede C, Eberhard J, Schweitzer A, Toikkanen SE, Glöckner S, Krause G, Stiesch M. 2018. Epidemiology and risk factors of peri-implantitis: A systematic review. $J$ Periodontal Res 53:657-681. DOI: 10.1111/jre.12562.

Gómez-Moreno G, Aguilar-Salvatierra A, Rubio Roldán J, Guardia J, Gargallo J, Calvo-Guirado JL. 2015. Peri-implant evaluation in type 2 diabetes mellitus patients: a 3-year study. Clin Oral Implants Res 26:1031-1035. DOI: 10.1111/clr.12391.

Gulia S, Bhatt V, Shetty M, Prasad KD, Gupta P. 2018. Effect of Type II Diabetes Mellitus, 
Candida Albicans and Streptococcus Mutans on the Biofilm Formation on Prosthetic Materials. J Contemp Dent Pract 19:1538-1545.

Héron E, Deloukas P, van Loon AP. 1995. The complete exon-intron structure of the 156-kb human gene NFKB1, which encodes the p105 and p50 proteins of transcription factors NF-

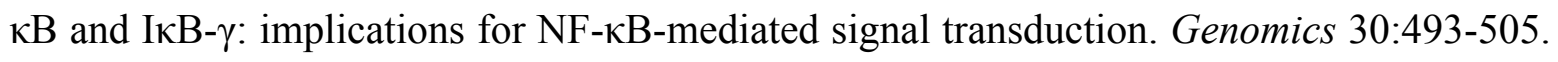
DOI: $10.1006 /$ geno.1995.1270.

Hochstrasser M. 1996. Ubiquitin-dependent protein degradation. Annu Rev Genet 30:405-439. DOI: 10.1146/annurev.genet.30.1.405. inhibition. J Biol Chem 280:14189-14202. DOI: 10.1074/jbc.M413660200.

Jin W, Dong C. 2013. IL-17 cytokines in immunity and inflammation. Emerg Microbes Infect, 2:e60. DOI: 10.1038/emi.2013.58.

Kim YG, Park JW, Lee JM, Suh JY, Lee JK, Chang BS, Um HS, Kim JY, Lee Y. 2014. IL-17 Diabetes 54:1074-1081. 
421

422

423

424

425

426

427

428

429

430

431

432

433

434

435

436

437

438

439

440

441

Hassdenteufel S, Tatzelt J, Kreutzer B, Edelmann L, Krause E, Rettig J, Somlo S, Zimmermann R, Dudek J. 2012. Different effects of Sec61 $\alpha$, Sec62 and Sec63 depletion on transport of polypeptides into the endoplasmic reticulum of mammalian cells. $J$ Cell Sci 125:1958-1969. DOI: $10.1242 /$ jcs.096727.

Lecker SH, Goldberg AL, Mitch WE. 2006. Protein degradation by the ubiquitin-proteasome pathway in normal and disease states. $J$ Am Soc Nephrol 17:1807-1819. DOI: 10.1681/ASN.2006010083.

Lee JS, Yi JK, An SY, Heo JS. 2014a. Increased osteogenic differentiation of periodontal ligament stem cells on polydopamine film occurs via activation of integrin and PI3K signaling pathways. Cell Physiol Biochem 34:1824-1834. DOI: 10.1159/000366381.

Lee S, Kim JY, Hwang J, Kim S, Lee JH, Han DH. 2014b. Investigation of pathogenic genes in peri-implantitis from implant clustering failure patients: a whole-exome sequencing pilot study. PLoS One 9:e99360. DOI: 10.1371/journal.pone.0099360.

Maj M, Hoermann G, Rasul S, Base W, Wagner L, Attems J. 2016. The microtubule-associated protein tau and its relevance for pancreatic beta cells. J Diabetes Res 2016:1964634. DOI: $10.1155 / 2016 / 1964634$.

Marin C, Luyten FP, Van der Schueren B, Kerckhofs G, Vandamme K. 2018. The impact of type 2 diabetes on bone fracture healing. Front Endocrinol (Lausanne) 9:6. DOI: 10.3389/fendo.2018.00006.

Candel-Martí ME, Flichy-Fernández AJ, Alegre-Domingo T, Ata-Ali J, Peñarrocha-Diago MA. 2011. Interleukins IL-6, IL-8, IL-10, IL-12 and periimplant disease. An update. Med Oral 
442

443

444

445

446

447

448

449

450

451

452

453

454

455

456

457

458

459

460

461

462

Patol Oral Cir Bucal 16:e518-21.

Monje A, Catena A, Borgnakke WS. 2017. Association between diabetes mellitus/hyperglycaemia and peri-implant diseases: Systematic review and meta-analysis. $J$ Clin Periodontol 44:636-648. DOI: 10.1111/jcpe.12724.

Nadeem A, Javaid K, Sami W, Zafar A, Jahan S, Zaman S, Nagi A. 2013. Inverse relationship of serum IL-17 with type-II diabetes retinopathy. Clin Lab 59:1311-7.

Nielsen TB, Pantapalangkoor P, Yan J, Luna BM, Dekitani K, Bruhn K, Tan B, Junus J, Bonomo RA, Schmidt AM, Everson M, Duncanson F, Doherty TM, Lin L, Spellberg B. 2017. Diabetes Exacerbates Infection via Hyperinflammation by Signaling through TLR4 and RAGE. MBio 8:e00818-17. DOI: 10.1128/mBio.00818-17.

Niswender KD, Morrison CD, Clegg DJ, Olson R, Baskin DG, Myers MG Jr, Seeley RJ, Schwartz MW. 2003. Insulin activation of phosphatidylinositol 3-kinase in the hypothalamic arcuate nucleus: a key mediator of insulin-induced anorexia. Diabetes $52: 227-231$.

Oeckinghaus A, Postler TS, Rao P, Schmitt H, Schmitt V, Grinberg-Bleyer Y, Kühn LI, Gruber

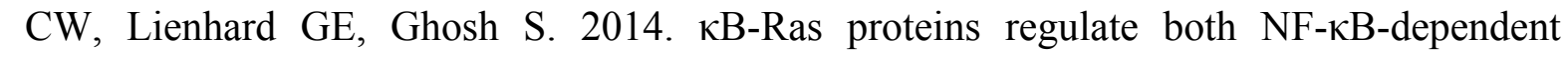
inflammation and Ral-dependent proliferation. Cell Rep 8:1793-1807. DOI: 10.1016/j.celrep.2014.08.015.

Pihlajamäki J, Boes T, Kim EY, Dearie F, Kim BW, Schroeder J, Mun E, Nasser I, Park PJ, Bianco AC, Goldfine AB, Patti ME. 2009. Thyroid hormone-related regulation of gene expression in human fatty liver. $J$ Clin Endocrinol Metab 94:3521-3529. DOI: 
10.1210/jc.2009-0212.

464 Piñero J, Bravo À, Queralt-Rosinach N, Gutiérrez-Sacristán A, Deu-Pons J, Centeno E, García465 García J, Sanz F, Furlong LI. 2016. DisGeNET: a comprehensive platform integrating information on human disease-associated genes and variants. Nucleic Acids Res 45:D833D839. DOI: $10.1093 / \mathrm{nar} / \mathrm{gkw} 943$.

Rakić M, Nikolić-Jakoba N, Struillout X, Petković-Curcin A, Stamatović N, Matić S, Janković S, Aleksić Z, Vasilić D, Leković V, Vojvodić D. 2013. Receptor activator of nuclear factor kappa B (RANK) as a determinant of peri-implantitis. Vojnosanit Pregl 70:346-51.

Ritchie ME, Phipson B, Wu D, Hu Y, Law CW, Shi W, Smyth GK. 2015. limma powers differential expression analyses for RNA-sequencing and microarray studies. Nuc Acid Res 43:e47. DOI: 10.1093/nar/gkv007.

Rehman K, Akash MSH, Liaqat A, Kamal S, Qadir MI, Rasul A. 2017. Role of interleukin-6 in development of insulin resistance and type 2 diabetes mellitus. Crit Rev Eukaryot Gene Expr 27:229-236. DOI: 10.1615/CritRevEukaryotGeneExpr.2017019712.

Renvert S, Persson GR, Pirih FQ, Camargo PM. 2018. Peri-implant health, peri-implant Periodontol 89 Suppl 1:S304-S312. DOI: 10.1002/JPER.17-0588.

Saadat M. 2017. Evaluation of glutathione S-transferase P1 (GSTP1) Ile105Val polymorphism and susceptibility to type 2 diabetes mellitus, a meta-analysis. EXCLI $J \quad$ 16:1188-1197. DOI: 10.17179/excli2017-828. 
F. 2016. Salivary Concentration of Oxidative Stress Biomarkers in a Group of Patients with

Peri-Implantitis: A Transversal Study. Clin Implant Dent Relat Res 18:1015-1022. DOI: 10.1111/cid.12367.

487

488

489

490

491

492

493

494

495

496

497

498

499

Savic-Radojevic A, Mimic-Oka J, Pljesa-Ercegovac M, Opacic M, Dragicevic D, Kravic T, Djokic M, Micic S, Simic T. 2007. Glutathione S-transferase-P1 expression correlates with increased antioxidant capacity in transitional cell carcinoma of the urinary bladder. Eur Urol 52:470-477. DOI: 10.1016/j.eururo.2007.01.046.

Schminke B, Vom Orde F, Gruber R, Schliephake H, Bürgers R, Miosge N. 2015. The pathology of bone tissue during peri-implantitis. $J$ Dent Res 94:354-361. DOI: $10.1177 / 0022034514559128$.

Severino VO, Beghini M, de Araújo MF, de Melo MLR, Miguel CB, Rodrigues WF, de Lima Pereira SA. 2016. Expression of IL-6, IL-10, IL-17 and IL-33 in the peri-implant crevicular fluid of patients with peri-implant mucositis and peri-implantitis. Arch Oral Biol 72:194199. DOI: 10.1016/j.archoralbio.2016.08.021.

Shrestha N1, Bahnan W, Wiley DJ, Barber G, Fields KA, Schesser K. 2012. Eukaryotic initiation factor 2 (eIF2) signaling regulates proinflammatory cytokine expression and bacterial invasion. J Biol Chem 287:28738-28744. DOI: 10.1074/jbc.M112.375915.

Sündermann F, Fernandez MP, Morgan RO. 2016. An evolutionary roadmap to the microtubuleassociated protein MAP Tau. BMC Genomics 17:264. DOI: 10.1186/s12864-016-2590-9.

Taneera J1, Fadista J, Ahlqvist E, Zhang M, Wierup N, Renström E, Groop L. 2013. Expression profiling of cell cycle genes in human pancreatic islets with and without type 2 diabetes. 
Mol Cell Endocrinol 375:35-42. DOI: 10.1016/j.mce.2013.05.003.

506

507

508

509

510

511

512

513

514

515

516

517

518

519

520

521

522

523

524

525

Teng Y, Qin H, Bahassan A, Bendzunas NG, Kennedy EJ, Cowell JK. 2016. The WASF3NCKAP1-CYFIP1 complex is essential for breast cancer metastasis. Cancer Res 76:51335142. DOI: 10.1158/0008-5472.CAN-16-0562.

Tunduguru R, Zhang J, Aslamy A, Salunkhe VA, Brozinick JT, Elmendorf JS, Thurmond DC. 2017. The actin-related p41ARC subunit contributes to p21-activated kinase-1 (PAK1)mediated glucose uptake into skeletal muscle cells. J Biol Chem 292:19034-19043. DOI: 10.1074/jbc.M117.801340.

Venza I, Visalli M, Cucinotta M, De Grazia G, Teti D, Venza M. 2010. Proinflammatory gene expression at chronic periodontitis and peri-implantitis sites in patients with or without type 2 diabetes. J Periodontol 81:99-108. DOI: 10.1902/jop.2009.090358.

Wang FS, Wang CJ, Huang HJ, Chung H, Chen RF, Yang KD. 2001. Physical shock wave mediates membrane hyperpolarization and Ras activation for osteogenesis in human bone marrow stromal cells. Biochem Biophys Res Commun 287:648-655. DOI: 10.1006/bbrc.2001.5654.

Wright E Jr, Scism-Bacon JL, Glass LC. 2006. Oxidative stress in type 2 diabetes: the role of fasting and postprandial glycaemia. Int J Clin Pract 60:308-314. DOI: 10.1111/j.13685031.2006.00825.x.

Yaghobee S, Khorsand A, Rasouli Ghohroudi AA, Sanjari K, Kadkhodazadeh M. 2014. Assessment of interleukin-1beta and interleukin-6 in the crevicular fluid around healthy implants, implants with peri-implantitis, and healthy teeth: a cross-sectional study. $J$ Korean 

Assoc Oral Maxillofac Surg 40:220-224. DOI: 10.5125/jkaoms.2014.40.5.220.

527

528

529

530

531

532

533

534

535

536

537

538

539

540

541

542

543

544

545

546

Yamada H, Nakajima T, Domon H, Honda T, Yamazaki K. 2015. Endoplasmic reticulum stress response and bone loss in experimental periodontitis in mice. J Periodontal Res 50:500-508. DOI: 10.1111/jre.12232.

You DJ, Park CR, Lee HB, Moon MJ, Kang JH, Lee C, Oh SH, Ahn C, Seong JY, Hwang JI. 2014. A splicing variant of NME1 negatively regulates NF-kappaB signaling and inhibits cancer metastasis by interacting with IKKbeta. $J$ Biol Chem 289:17709-20. DOI: 10.1074/jbc.M114.553552.

Yousefidaredor H, Zare-Bidaki M, Hakimi H, Assar S, Bagheri V, Arababadi MK. 2014. IL-17A plays an important role in induction of type 2 diabetes and its complications. Asian Pac $J$ Trop Dis 4:412-415. DOI: 10.1016/S2222-1808(14)60598-3.

Yousif MH, Benter IF, Abraham S, Akhtar S. 2004. Inhibition of Ras-GTPase improves diabetes-induced abnormal vascular reactivity in the rat perfused mesenteric vascular bed. Med Princ Pract 13:57-62. DOI: 10.1159/000075629.

Zhang H, Zhang X, Huang J, Fan X. 2017. Identification of key genes and pathways for periimplantitis through the analysis of gene expression data. Exp Ther Med 13: 1832-1840. DOI: 10.3892/etm.2017.4176.

Zou W, Greenblatt MB, Brady N, Lotinun S, Zhai B, de Rivera H, Singh A, Sun J, Gygi SP, Baron R, Glimcher LH, Jones DC. 2013. The microtubule-associated protein DCAMKL1 regulates osteoblast function via repression of Runx2. J Exp Med 210:1793-806. DOI: 
Figure 1

Fig 1

The PPI network of DEGs expressed in periimplantitis (a), and PPI network of genes related to type 2 diabetes (b). 


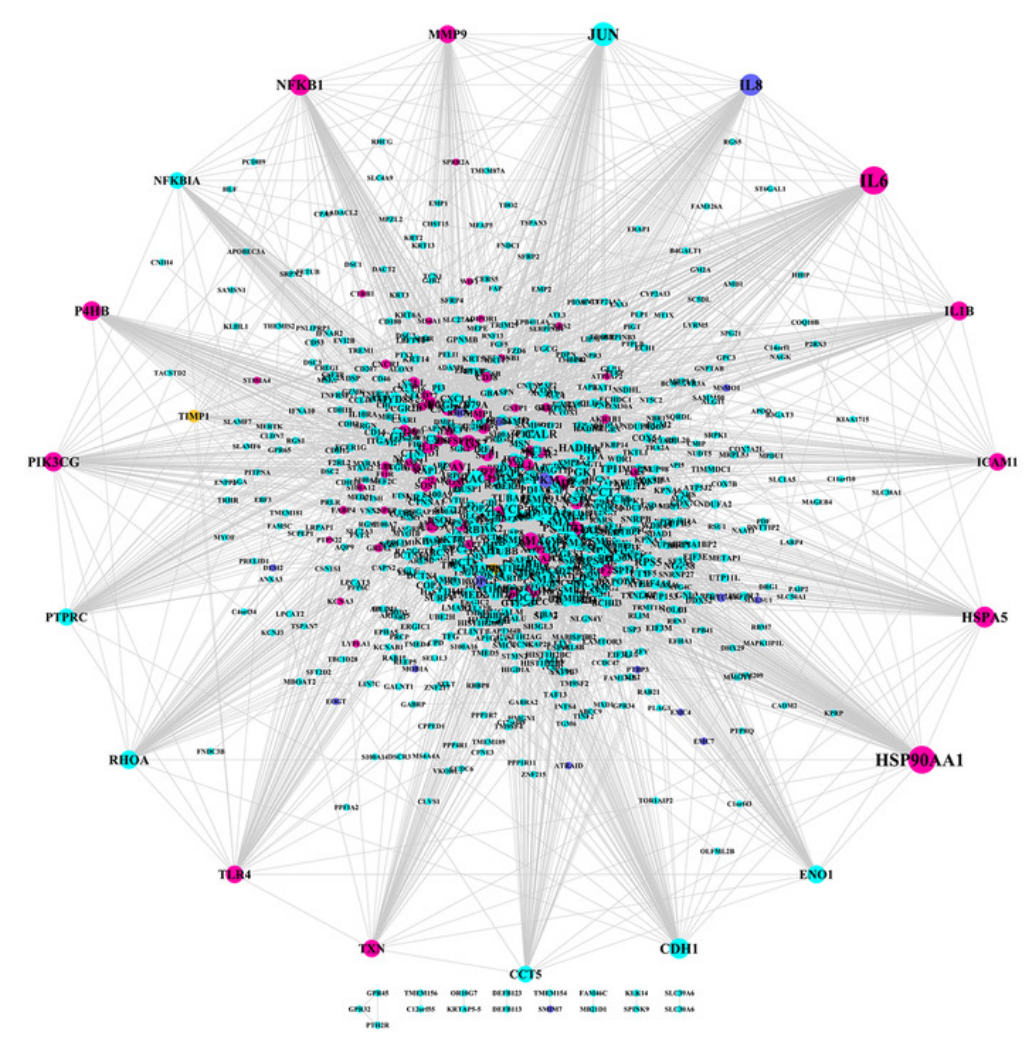

a.Periimplantitis

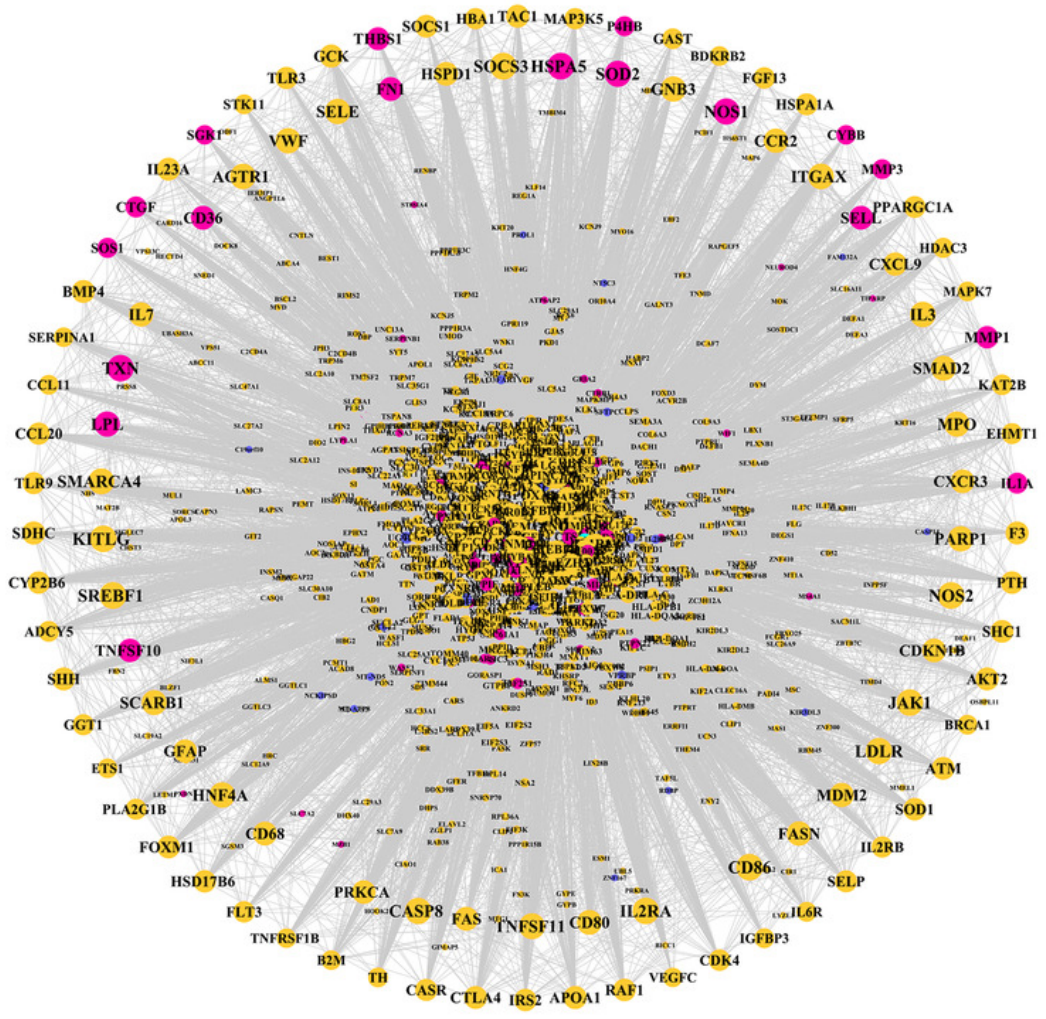

b.Diabetes

Diabetes 
Figure 2

Fig 2.

The PPI subnetwork of IL6 (a) $\square$ NFKB1 (b) , and PIK3CG (c).
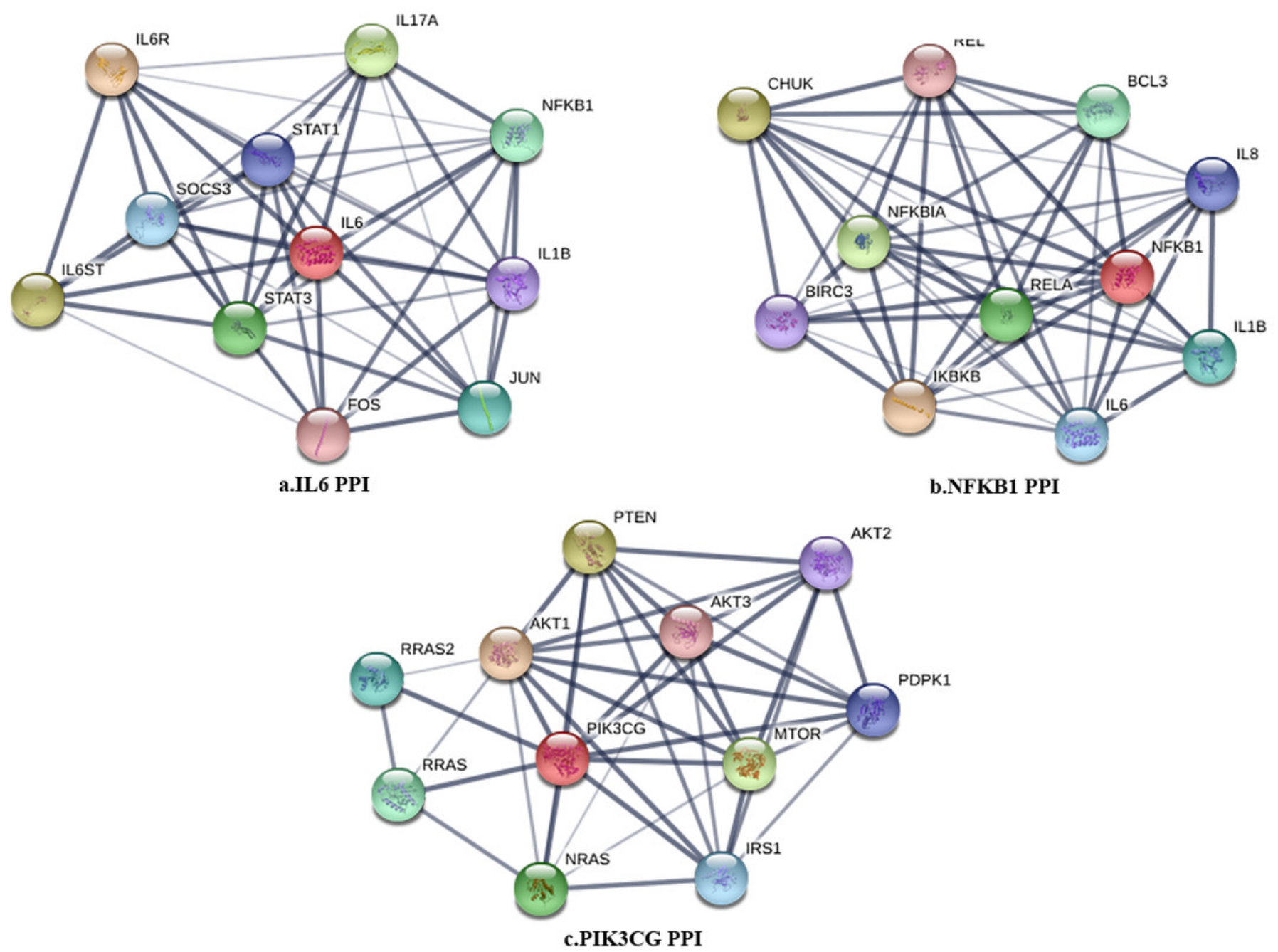
Figure 3

Fig 3.

Fig 3. The module network 1 identified two cross-talk genes (PSMD1 and PSMD6).

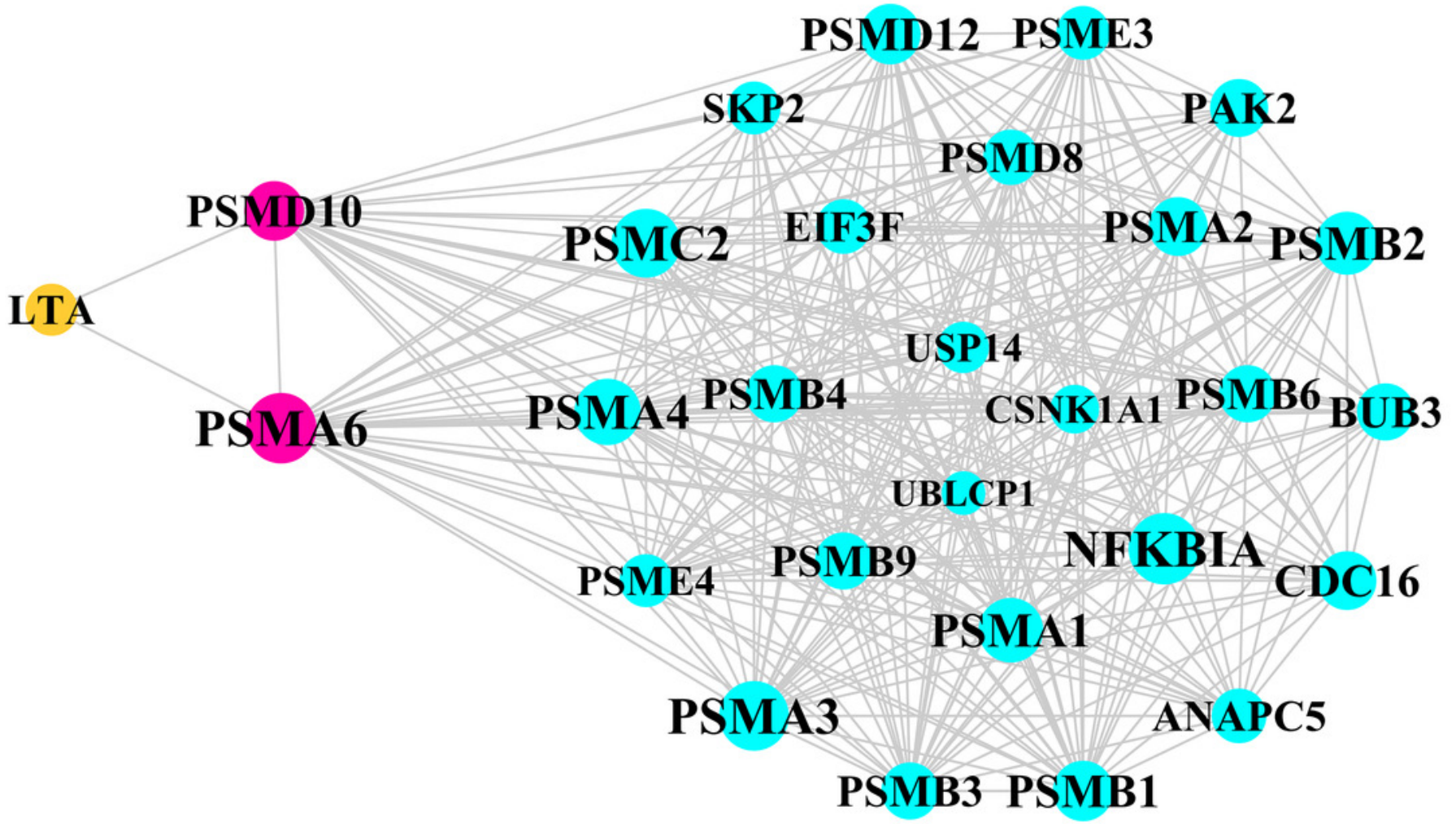

Diabetes

Periimplantitis DEG

common 


\section{Figure 4}

Fig 4.

The module network 2 identified five cross-talk genes (EIF2S1, GSTP1, DNAJC3, SEC61A1, and MAPT).

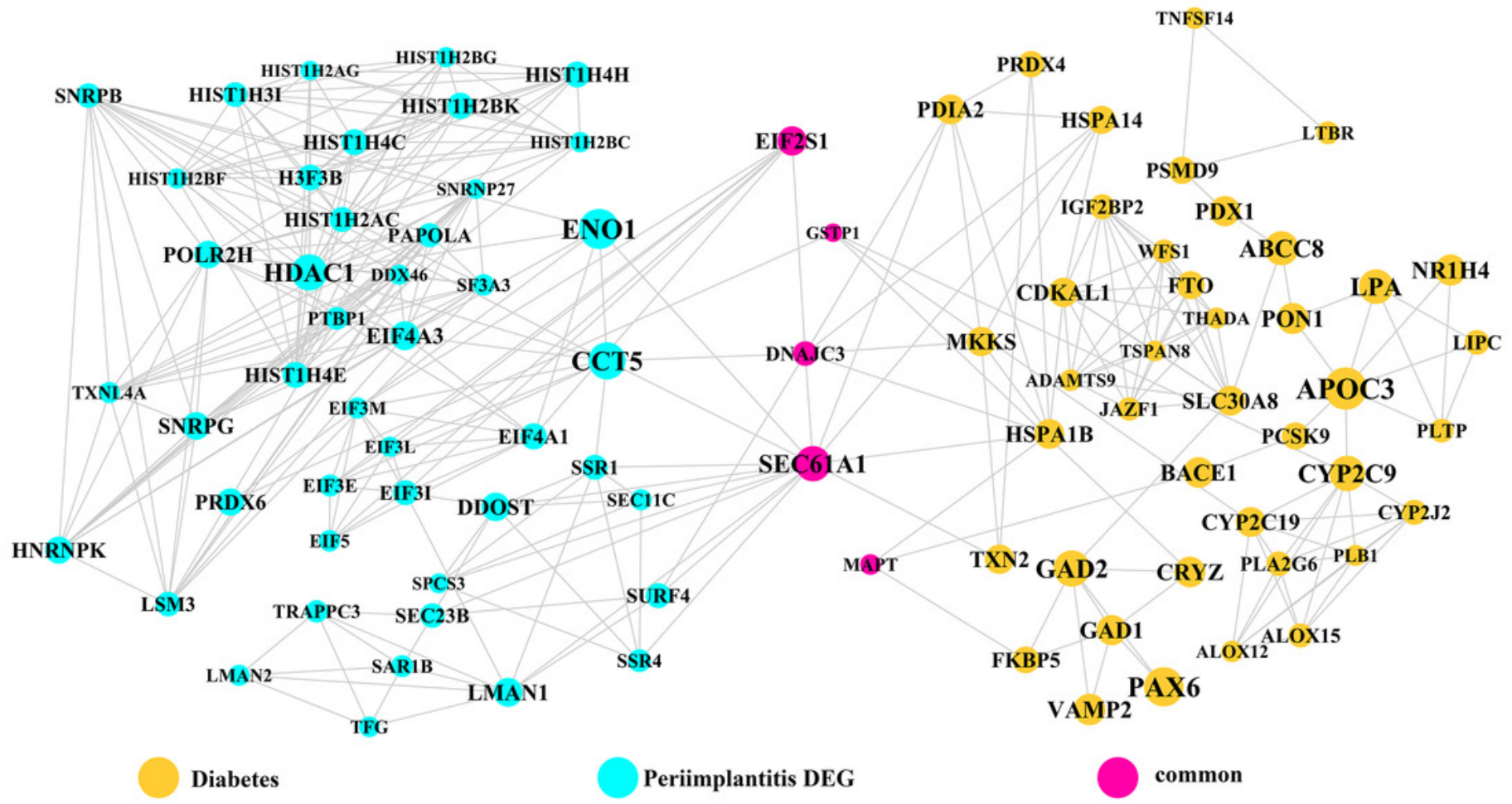




\section{Figure 5}

Fig 5 .

The module subnetwork 3 identified only one cross-talk gene (NME1).

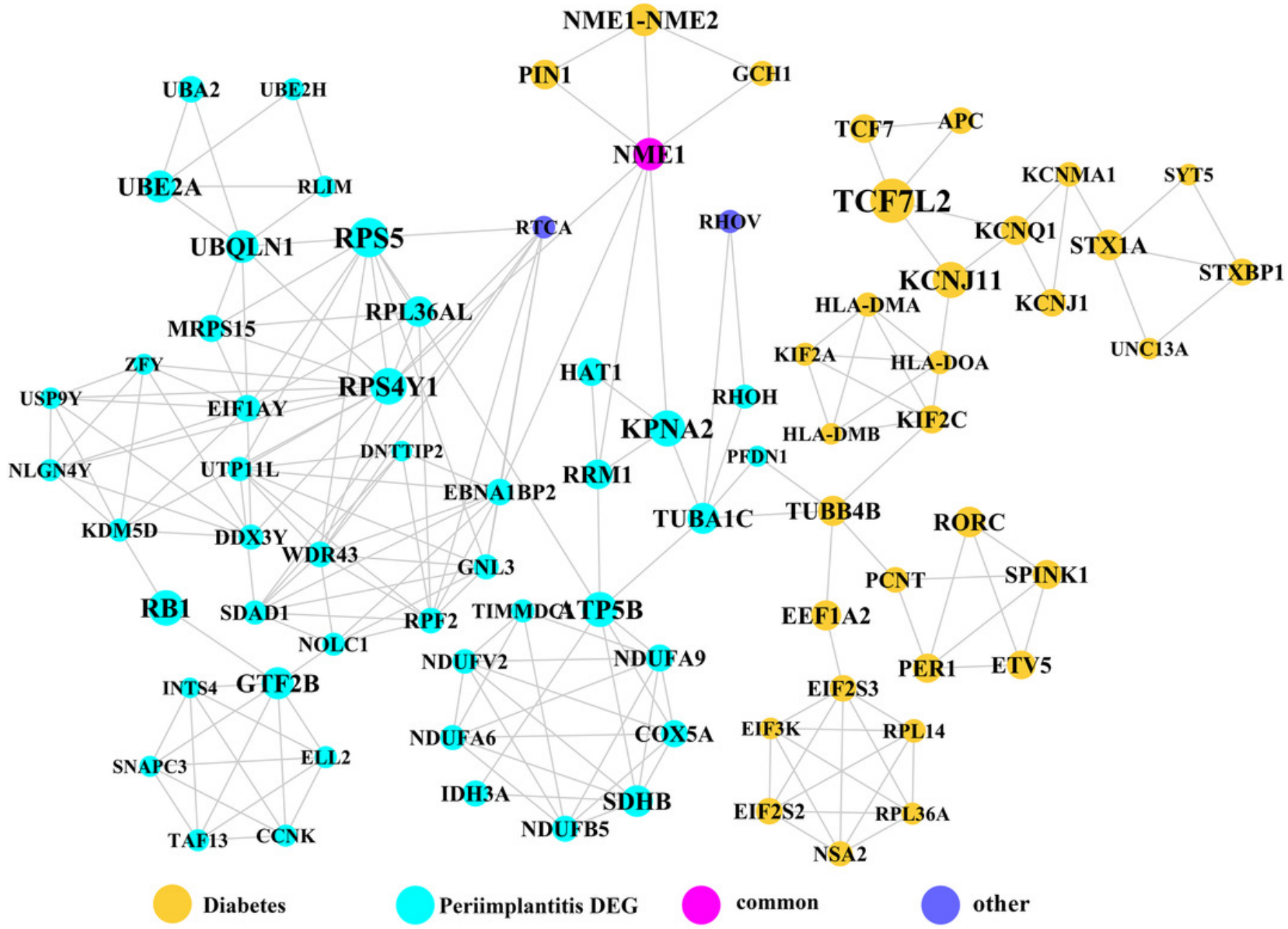




\section{Table $\mathbf{1}$ (on next page)}

Table 1

The functions of genes identified in the pathogenesis of T2DM and periimplantitis respectively. 
Table 1. The functions of genes identified in the pathogenesis of T2DM and periimplantitis respectively.

\begin{tabular}{|c|c|c|c|}
\hline Genes & General functions & Functions in T2DM & Functions in periimplantitis \\
\hline IL-6 & $\begin{array}{l}\text { Interleukin } 6 \text { (IL-6) is an interleukin } \\
\text { that acts as both a pro-inflammatory } \\
\text { cytokine and an anti-inflammatory } \\
\text { myokine. }\end{array}$ & $\begin{array}{l}\text { (1) has an anti-inflammatory role and } \\
\text { improves glucose metabolism; } \\
\text { (2) induces the development of insulin } \\
\text { resistance and pathogenesis of T2DM } \\
\text { through the generation of inflammation by } \\
\text { controlling differentiation, migration, } \\
\text { proliferation, and cell apoptosis. }\end{array}$ & $\begin{array}{l}\text { (1) exert proinflammatory } \\
\text { effects; } \\
\text { (2) induce bone resorption. }\end{array}$ \\
\hline NFKB1 & $\begin{array}{l}\text { NFKB1 (Nuclear Factor Kappa B } \\
\text { Subunit 1) encodes a } 105 \mathrm{kD} \text { protein } \\
\text { which is a DNA binding subunit of } \\
\text { the NF-kappa-B (NFKB) protein } \\
\text { complex. }\end{array}$ & $\begin{array}{l}\text { (1) be involved in a compensatory mechanism } \\
\text { that develops in } \beta \text {-cells during the loss of } \\
\text { insulin sensitivity; } \\
\text { (2) be implicated in the expression of } \\
\text { GLUT2, which contributes to glucose- } \\
\text { stimulated insulin secretion by } \beta \text {-cells; } \\
\text { (3) Its inhibition may have deleterious effects } \\
\text { leading to the development of insulin } \\
\text { resistance and type } 2 \text { diabetes. }\end{array}$ & $\begin{array}{l}\text { (1) regulate the inflammatory- } \\
\text { induced osteoclastogenesis } \\
\text { process; } \\
\text { (2) regulate receptor activator of } \\
\text { NF- } \mathrm{B} \text { ligand (RANKL) - } \\
\text { mediated osteoclast } \\
\text { formation and activation. }\end{array}$ \\
\hline $\begin{array}{l}\text { PIK3CG } \\
\text { (also } \\
\text { called } \\
\text { PI3K) }\end{array}$ & $\begin{array}{l}\text { (1) a family of lipid kinases that } \\
\text { catalyze the phosphorylation of } \\
\text { plasma membrane lipid } \\
\text { phosphatidylinositol; } \\
\text { (2) Being involved in PI3K/AKT } \\
\text { pathway. }\end{array}$ & $\begin{array}{l}\text { Its reduction impairs insulin signal } \\
\text { transduction, resulting in the impaired } \\
\text { translocation of glucose transporter protein } \\
\text { GLUT4 and insulin resistance. }\end{array}$ & $\begin{array}{l}\text { (1) Be correlated with } \\
\text { inflammation regulation, } \\
\text { angiogenesis, and osteoclast } \\
\text { activity; } \\
\text { (2) PI3K signaling can lead to } \\
\text { osteogenic induction and } \\
\text { increased osteogenic } \\
\text { differentiation of Periodontal } \\
\text { Ligament Stem Cells } \\
\text { (PDLSCs), thus PI3K could }\end{array}$ \\
\hline
\end{tabular}




\begin{tabular}{|c|c|c|c|}
\hline & & & $\begin{array}{l}\text { be involved in } \\
\text { periimplantitis via regulation } \\
\text { of peri-implant osteogenesis. }\end{array}$ \\
\hline WASF3 & $\begin{array}{l}\text { WASF3 (Wiskott-Aldrich syndrome } \\
\text { protein family member } 3 \text { ) plays a role } \\
\text { in the regulation of cell morphology } \\
\text { and cytoskeletal organization. }\end{array}$ & $\begin{array}{l}\text { (1) plays a role in the remodeling of actin } \\
\text { cytoskeleton, which is involved in the } \\
\text { regulation of pancreatic } \beta \text {-cell insulin } \\
\text { secretion. } \\
\text { (2) Regulate cell morphology; red cell } \\
\text { morphology changes have been observed } \\
\text { in T2DM patients with high prevalence. }\end{array}$ & $\begin{array}{l}\text { Actin binding was shown to be } \\
\text { significant biological process in } \\
\text { periimplantitis, thus WASF3 } \\
\text { may be involved in } \\
\text { periimplantitis by controlling } \\
\text { actin binding. }\end{array}$ \\
\hline
\end{tabular}




\begin{tabular}{|c|c|c|c|}
\hline EIF2S1 & $\begin{array}{l}\text { EIF2S1 (Eukaryotic translation } \\
\text { initiation factor } 2 \text { subunit } 1 \text { ) is a } \\
\text { component of the PI3K pathway, } \\
\text { encoding for eukaryotic initiation } \\
\text { factor } 2 \alpha(\mathrm{eIF} 2 \alpha) \text {, the phosphorylation } \\
\text { of which can reduce protein synthesis }\end{array}$ & $\begin{array}{l}\text { dysregulation of eIF } 2 \alpha \text { phosphorylation is } \\
\text { poorly tolerated by pancreatic } \beta \text { cells, leading } \\
\text { to dysfunction. }\end{array}$ & $\begin{array}{l}\text { downregulates infection-induced } \\
\text { cytokine expression, thus } \\
\text { involved in the immune } \\
\text { inflammatory response. }\end{array}$ \\
\hline SEC61A1 & $\begin{array}{l}\text { SEC61A1 (Sec61 Translocon Alpha } 1 \\
\text { Subunit) plays a crucial role in the } \\
\text { insertion of secretory and membrane } \\
\text { polypeptides into the endoplasmic } \\
\text { reticulum (ER). }\end{array}$ & $\begin{array}{l}\text { Has the similar mechanism with DNAJC3: } \\
\text { be involved in the development of T2DM } \\
\text { since the disruption of its mediated ER can } \\
\text { cause the dysfunction of insulin-secreted beta } \\
\text { cells. }\end{array}$ & $\begin{array}{l}\text { Has the similar mechanism with } \\
\text { DNAJC3: } \\
\text { be involved in periimplantitis by } \\
\text { activating the unfolded protein } \\
\text { response (UPR) pathway } \\
\text { associated with inflammation } \\
\text { and alveolar bone resorption. }\end{array}$ \\
\hline
\end{tabular}




\begin{tabular}{|c|c|c|c|}
\hline МАРТ & $\begin{array}{l}\text { MAPT (microtubule associated } \\
\text { protein Tau), a neural phosphoprotein } \\
\text { member of the MAP family, is } \\
\text { implicated in microtubule function } \\
\text { within the cell cytoskeleton }\end{array}$ & $\begin{array}{l}\text { Disturbance in MAPT phosphorylation is } \\
\text { shown to decrease insulin production from } \\
\text { pancreatic beta cells. }\end{array}$ & $\begin{array}{l}\text { Be implicated in bone mineral } \\
\text { density regulation. }\end{array}$ \\
\hline NME1 & $\begin{array}{l}\text { NME1 (NME/NM23 Nucleoside } \\
\text { Diphosphate Kinase 1) is a negative } \\
\text { regulator of nuclear factor- } \mathrm{kB} \text { (NF- } \\
\mathrm{kB} \text { ) signaling which is a critical } \\
\text { player in immune responses. }\end{array}$ & $\begin{array}{l}\text { The inhibited activity of NF-kB can improve } \\
\text { conductance artery function in T2DM, thus } \\
\text { NME } 1 \text { may be involved in the T2DM by } \\
\text { impairing the artery function. }\end{array}$ & $\begin{array}{l}\text { (1) Inhibition of NF- } \mathrm{B} \text { can } \\
\text { prevent the inflammatory } \\
\text { response } \\
\text { periimplantitis, thus NME1 } \\
\text { may be involved in } \\
\text { periimplantitis; } \\
\text { (2) Receptor activator of nuclear } \\
\text { factor kappa B (RANK) was } \\
\text { shown to be a pathologic } \\
\text { determinant of } \\
\text { periimplantitis, thus NME1 } \\
\text { may be involved in } \\
\text { periimplantitis. }\end{array}$ \\
\hline
\end{tabular}

